Nuraini, A. • D. Sobardini · E. Suminar · H. Apriyanto

\title{
Kuantitas dan kualitas hasil benih buncis tegak (Phaseolus vulgaris L.) yang diberi pupuk organik padat dan pupuk organik cair chitosan
}

\section{Quantity and yield quality of french bean seed (Phaseolus vulgaris L.) marked solid organic fertilizer and chitosan liquid organic fertilizer}

\author{
Diterima : 15 Juli 2016/Disetujui : 10 Agustus 2016 / Dipublikasikan : 30 Agustus 2016 \\ CDepartment of Crop Science, Padjadjaran University
}

\begin{abstract}
This experiment aims to determine the effect of the interaction between type of solid organic fertilizers and liquid organic fertilizer chitosan that can give the best effect on growth, quantity and quality of yield french bean seed. The experiment was conducted at the Seed Technology Laboratory and the Experimental Station Faculty of Agriculture, Universitas Padja-djaran, Jatinangor. These experiments used factorial randomized block design with three replications. Types of solid organic fertilizers as the first factor consists of three levels, namely without solid organic fertilizers, chicken manure, and vermicompost. Concentration of chitosan as second factor consisted of four levels, namely $0,1,5,3$, and 4,5 $\mathrm{ml} \mathrm{L}^{-1}$. The experimental results showed that there was interaction effect between type of solid organic fertilizers and liquid organic fertilizer chitosan on seed germination. Chicken manure has the better effect than vermicompost fertilizer treatments on viability and vigor of seed. Concentration of $3 \mathrm{ml} \mathrm{L}^{-1}$ chitosan gave a better effect on seed vigor parameters.
\end{abstract}

Keywords : French bean - Chitosan - Chicken manure $\cdot$ Vermicompost

Sari Percobaan ini bertujuan untuk mengetahui pengaruh interaksi antara jenis pupuk organik padat dan pupuk organik cair (POC) chitosan yang dapat memberikan pengaruh terbaik terhadap pertumbuhan, kuantitas dan kualitas hasil benih buncis tegak. Percobaan dilakukan dari bulan Maret 2012 hingga Juni 2012 di

Dikomunikasikan oleh Agus Wahyudin

Nuraini, A. ${ }^{1}$. D. Sobardini ${ }^{1}$. E. Suminar ${ }^{1}$

H. Apriyanto ${ }^{2}$

1 Staf pengajar Program Studi Agroteknologi Fakultas

Pertanian UNPAD

2 Alumni Program Studi Agroteknologi Fakultas

Pertanian UNPAD

Korespondensi : nuraini_yunandar@yahoo.com
Kebun Percobaan Fakultas Pertanian Universitas Padjadjaran, Jatinangor, Jawa Barat. Percobaan ini menggunakan Rancangan Acak Kelompok Faktorial dengan tiga ulangan. Faktor pertama adalah jenis pupuk organik padat terdiri dari tiga taraf, yaitu tanpa pupuk organik padat, pupuk kandang ayam, dan kascing. Faktor kedua adalah konsentrasi POC chitosan terdiri dari empat taraf yaitu : $0 \mathrm{ml} \mathrm{L}^{-1}, 1,5 \mathrm{ml} \mathrm{L}^{-1}, 3 \mathrm{ml}$ $\mathrm{L}^{-1}$, dan $4,5 \mathrm{ml} \mathrm{L}^{-1}$. Hasil percobaan menunjukkan bahwa terdapat pengaruh interaksi antara pupuk organik padat dan POC chitosan terhadap daya berkecambah benih. Pemberian pupuk organik padat dapat meningkatkan viabilitas dan vigor benih buncis tegak, pupuk kandang ayam memiliki pengaruh yang lebih dibandingkan kascing. Konsentrasi $3 \mathrm{ml} \mathrm{L}^{-1}$ chitosan memberikan pengaruh yang terbaik terhadap parameter vigor benih.

Kata kunci : Buncis tegak · Pupuk kandang ayam $\cdot$ Kascing $\cdot$ Chitosan

\section{Pendahuluan}

Tanaman buncis (Phaseolus vulgaris L.) merupakan salah satu sayuran kelompok kacang-kacangan. Buncis ini memiliki 2 tipe pertumbuhan yaitu tipe tegak dan tipe merambat. Dibandingkan tipe merambat, buncis tipe tegak ini memiliki keunggulan diantaranya budidayanya tidak memerlukan ajir sehingga bisa menurunkan biaya produksi sebesar 30\% serta populasi tanaman buncis tegak per hektarnya lebih banyak daripada buncis tipe merambat, rata-rata populasinya mencapai 150.000-200.000 tanaman per hektar, sedangkan populasi per hektar buncis merambat hanya setengahnya (Pitojo, 2004).

Produktivitas buncis masih belum stabil, sedangkan nilai kebutuhan konsumsi buncis 
terus mengalami peningkatan. Dalam hal pengadaan benih buncis Indonesia hanya mampu berada pada peringkat 12 di dunia padahal pada tahun 2010 Indonesia merupakan negara ke dua terbesar penghasil buncis segar di dunia (FAO, 2011). Salah satu usaha yang dapat dilakukan adalah diperlukan pemenuhan kebutuhan benih bermutu tinggi untuk mendukung peningkatan produksi tanaman buncis.

Benih yang berkualitas tinggi diperoleh bila selama penanaman kebutuhan unsur hara dapat dipenuhi, sehingga pertumbuhan tanaman menjadi optimal. Penggunaan pupuk anorganik yang berlebihan menyebabkan terjadinya kerusakan tanah. Oleh karena itu diperlukan penggunaan pupuk organik yang tepat untuk meningkatkan produksi buncis. Pupuk organik mempunyai keunggulan yaitu dapat memberikan tambahan bahan organik dan mengandung unsur hara makro juga mengandung unsur mikro dalam jumlah yang cukup yang sangat diperlukan untuk pertumbuhan tanaman (Sutanto, 2002). Pupuk organik ini cukup banyak macamnya, diantaranya yaitu pupuk kandang dan pupuk organik cair.

Menurut Balasubramanian dan Bell (2005), pupuk kandang digunakan untuk meningkatkan kesuburan tanah dan kadar bahan organik tanah serta menyediakan hara mikro dan faktorfaktor pertumbuhan lain yang tidak disediakan oleh pupuk anorganik. Penggunaan pupuk kandang juga dapat meningkatkan pertumbuhan mikroba dan pemutaran hara dalam tanah. Hal ini memungkinkan petani untuk menggunakan pupuk kandang yang tersedia dengan biaya rendah untuk memenuhi kebutuhan tanaman akan unsur hara. Pupuk kandang yang mengandung unsur hara yang tinggi adalah kotoran ayam. Kandungan unsur hara pupuk kandang ayam tiga kali lebih besar dari hewan ternak lainnya (Musnamar, 2003).

Selain dari pupuk kandang ayam, kascing merupakan bahan organik yang mengandung unsur hara yang lengkap, baik unsur makro maupun mikro yang berguna bagi pertumbuhan tanaman. Kascing mempunyai struktur remah, sehingga dapat mempertahankan kestabilan dan aerasi tanah. Kandungan kascing tergantung pada bahan organik dan jenis cacingnya. Namun, umumnya kascing mengandung unsur hara nitrogen, fosfor, mineral dan vitamin yang dibutuhkan tanaman (Mulat, 2003).

Selain pupuk organik dengan bentuk padat, pupuk organik cair (POC) merupakan salah satu jenis pupuk yang banyak beredar di pasaran diantaranya Chitosan. Di bidang pertanian, chitosan digunakan terutama sebagai perlakuan benih organik dan meningkatkan pertumbuhan tanaman, dan sebagai zat biopestisida ramah lingkungan yang meningkatkan kemampuan suatu tanaman untuk tahan terhadap infeksi jamur. Pemanfaatan chitosan sebagai bahan untuk meningkatkan pertumbuhan tanaman sedang banyak dikaji pengaruhnya terhadap berbagai jenis tanaman.

Pemberian POC harus memperhatikan konsentrasi atau dosisnya. Semakin tinggi dosis pupuk yang diberikan maka unsur hara yang diterima oleh tanaman akan semakin tinggi. Namun, pemberian dengan dosis yang berlebihan justru akan mengakibatkan timbulnya gejala kelayuan pada tanaman (Suwandi dan Nurtika, 1987). Sehubungan dengan itu, perlu dilakukan penelitian tentang pengaruh jenis pupuk organik padat dan konsentrasi pupuk organik cair chitosan terhadap kuantitas dan kualitas benih buncis tipe tegak.

\section{Bahan dan Metode}

Penelitian dilakukan di Laboratorium Teknologi Benih dan Kebun Percobaan Ciparanje Fakultas Pertanian Universitas Padjadjaran Jatinangor, Kabupaten Sumedang, dengan ketinggian tempat sekitar \pm 750 meter di atas permukaan laut (dpl), pada tanah ordo Inceptisol dan tipe curah hujan D3 menurut Oldeman.

Bahan-bahan yang digunakan meliputi : benih buncis tipe tegak kultivar Kenya, pupuk dasar organik (Petroganik), pupuk kandang ayam dan pupuk organik kascing, pupuk organik cair chitosan chi farm, tanah, air, kertas merang untuk uji daya berkecambah, pelapis benih (Cruiser), insektisida Curacron 500 EC, fungisida (Saaf 75 WP dan Amistartop 325 SC), Carbofuran 50 WP. Alat-alat yang digunakan meliputi: alat pengolah lahan (cangkul, sekop, tugal, dan kored), mulsa plastik hitam perak, , ember, alat penyemprot pestisida, timbangan teknis dan analitik, hand sprayer pompa, oven, alat-alat untuk uji daya berkecambah (plastik, tali rafia, pinset dan germinator)

Percobaan dilaksanakan dengan Rancangan Acak Kelompok (RAK) pola faktorial yang terdiri dari dua faktor dan tiga kali ulangan. Faktor I adalah jenis pupuk organik padat $(\mathrm{O})$ terdiri dari tiga taraf, yaitu: $\mathrm{O}_{1}=$ tanpa pemberian pupuk organik padat, $\mathrm{O}_{2}=$ pupuk kandang ayam dosis 20 ton $/ \mathrm{ha}=2 \mathrm{~kg} \mathrm{~m}^{-2}, \mathrm{o}_{3}=$ pupuk organik kascing 
dosis 7 ton $/$ ha $=0,7 \mathrm{~kg} \mathrm{~m}^{-2}$. Faktor II adalah pupuk organik cair chitosan (C) terdiri dari empat taraf, yaitu: $\mathrm{c}_{1}=$ tanpa POC, $\mathrm{c}_{2}=1,5 \mathrm{~mL} \mathrm{~L}^{-1}, \mathrm{c}_{3}=3 \mathrm{~mL} \mathrm{~L}^{-1}$, dan $\mathrm{c}_{4}=4,5 \mathrm{~mL} \mathrm{~L}^{-1}$. Data diuji dengan uji $\mathrm{F}$ dilanjutkan dengan Uji Jarak Berganda Duncan pada taraf $5 \%$.

Pupuk petroganik sebagai pupuk dasar diberikan dengan cara disebar merata sebanyak 2 ton ha ${ }^{-1}$ kemudian diberi insektisida dengan bahan aktif Carbofuran 50 WP (Furadan) dengan cara disebar merata, setelah itu ditutup dengan mulsa plastik hitam perak. Aplikasi pupuk organik padat diberikan seminggu sebelum tanam dengan dosis sesuai perlakukan. Sebelum ditanam, benih buncis tegak diberi pelapis benih (Cruiser). Perlakuan tersebut dilakukan 2 jam sebelum tanam. Setiap lubang tanam diberikan Carbofuran 50 WP.

Aplikasi Chitosan (Chi farm) dilakukan 7 kali, aplikasi pertama saat tanaman berumur 2 minggu setelah tanam (MST), kemudian setiap interval 1 minggu sampai 8 MST. Chitosan diaplikasikan melalui daun, dosisnya ditentukan melalui kalibrasi. Pemanenan dilakukan pada saat masak fisiologis yaitu ketika polong telah matang dan berwarna kecoklatan, kering, tapi belum pecah. Pengamatan dilakukan terhadap : jumlah polong isi per tanaman (buah), jumlah biji per polong (butir), jumlah biji per tanaman, bobot biji per tanaman $(\mathrm{g})$, bobot 100 butir benih (g), Daya Berkecambah benih, dan Indeks vigor.

\section{Hasil dan Pembahasan}

Jumlah Polong dan Biji per Tanaman, Jumlah Biji per Polong, Bobot Biji per Tanaman, dan Bobot 100 Butir. Interaksi pupuk organik padat dan chitosan tidak mempengaruhi kuantitas benih. Pemberian pupuk organik padat memberikan pengaruh yang nyata terhadap jumlah polong per tanaman, jumlah biji per tanaman dan bobot biji per tanaman, tetapi tidak memberikan pengaruh nyata pada jumlah biji per polong dan bobot 100 butir biji. Pemberian chitosan tidak memberikan pengaruh yang nyata terhadap jumlah polong per tanaman, jumlah biji per tanaman, jumlah biji per polong, bobot biji per tanaman dan bobot 100 butir (Tabel 1).

Pemberian pupuk kandang ayam menghasilkan jumlah polong per tanaman, jumlah biji per tanaman dan bobot biji per tanaman yang paling tinggi dibandingkan dengan tanpa pupuk organik padat dan kascing.
Pupuk kandang ayam sebagai salah satu sumber bahan organik mengandung unsur hara $\mathrm{P}$ yang relatif lebih tinggi dari pupuk kandang lainnya. Kadar unsur $\mathrm{K}$ dalam pupuk kandang ayam cukup tinggi yaitu berkisar 1,0-1,4\%, sehingga diharapkan dapat meningkatkan ketersediaan $\mathrm{K}$ bagi kebutuhan tanaman. Kelebihan lain yang dimiliki oleh pupuk kandang ayam yaitu dapat meningkatkan kadar humus, sebagai sumber bahan organik, memperbaiki struktur tanah dan meningkatkan $\mathrm{pH}$ tanah (Widowati, 2006). Menurut Musnamar (2003), pupuk organik memberikan manfaat berupa meningkatkan kesuburan tanah, memperbaiki kondisi kimia, fisika, dan biologi tanah sehingga dapat mening katkan produksi pertanian. Kandungan unsur hara pupuk kandang ayam tiga kali lebih besar dari hewan ternak lainnya.

Pada Tabel 1 dapat dilihat pemberian pupuk organik cair chitosan tidak memberikan pengaruh terhadap jumlah polong per tanaman, jumlah biji per tanaman, jumlah biji per polong, bobot biji per tanaman dan bobot 100 butir, tetapi ada kecenderungan chitosan dapat meningkatkan bobot biji per tanaman. Hasil penelitian Chibu dan Shibayama (2001) menyatakan bahwa pemberian chitosan dengan konsentrasi 0,5\% pada beberapa tanaman meningkatkan bobot kering biji kedelai dan menunjukkan peningkatan hasil bobot buah tomat.

Pemberian pupuk organik padat dan pupuk organik cair chitosan tidak berpengaruh terhadap jumlah biji per polong, dan bobot 100 butir biji karena parameter tersebut lebih dipengaruhi oleh faktor genetik.

Daya Berkecambah Benih. Daya berkecambah benih dipengaruhi oleh interaksi pupuk organik padat dan pupuk organik cair chitosan (Tabel 2). Pemberian pupuk organik padat dapat meningkatkan daya berkecambah benih pada tanaman buncis tegak pada tanaman yang tidak diberi chitosan, tetapi pada yang diberi chitosan 1,5, 3 dan 4,5 $\mathrm{mL} \mathrm{L}^{-1}$ pemberian pupuk organik padat tidak meningkatkan daya berkecambah benih. Hal ini disebabkan keperluan pupuk organik sudah terpenuhi dari pupuk organik cair chitosan. Chitosan selain berperan khusus sebagai anti jamur juga dapat memperkuat sistem akar dan batang yang dapat memperkuat perkecambahan dan pertumbuhan (Wulandini, 2002).

Pemberian pupuk organik cair chitosan dapat meningkatkan daya berkecambah benih pada tanaman yang tidak diberi pupuk organik padat, tetapi pada tanaman yang diberi pupuk kandang ayam pemberian chitosan tidak meningkatkan daya bekecambah benih. Perlakuan yang paling 
Tabel 1. Pengaruh Pupuk Organik Padat dan Chitosan terhadap Jumlah Polong dan Biji per Tanaman, Jumlah Biji per Polong, dan Bobot Biji per Tanaman.

\begin{tabular}{|c|c|c|c|c|c|}
\hline Perlakuan & $\begin{array}{c}\text { Jumlah Polong } \\
\text { Per Tan } \\
\end{array}$ & $\begin{array}{c}\text { Jumlah Biji } \\
\text { Per Tan } \\
\end{array}$ & $\begin{array}{l}\text { Jumlah Biji } \\
\text { Per Polong } \\
\end{array}$ & $\begin{array}{c}\text { Bobot Biji } \\
\text { Per Tan (g) }\end{array}$ & $\begin{array}{c}\text { Bobot } 100 \\
\text { Butir (g) }\end{array}$ \\
\hline \multicolumn{6}{|l|}{ Pupuk Organik Padat: } \\
\hline Tanpa Pupuk & $13,40 \mathrm{ab}$ & $58,48 \mathrm{a}$ & $4,35 \mathrm{a}$ & $9,54 \mathrm{ab}$ & $17.09 \mathrm{a}$ \\
\hline Pupuk Kandang Ayam $20 \mathrm{t} \mathrm{ha}^{-1}$ & $15,76 \mathrm{~b}$ & $70,49 \mathrm{~b}$ & $4,50 \mathrm{a}$ & $11,11 \mathrm{~b}$ & $17.22 \mathrm{a}$ \\
\hline Pupuk Kascing 7 t ha-1 & $13,00 \mathrm{a}$ & 53,96 a & $4,22 \mathrm{a}$ & 9,03 a & $17.29 \mathrm{a}$ \\
\hline \multicolumn{6}{|l|}{ Pupuk Organik Cair : } \\
\hline Chitosan $0 \mathrm{~mL} \mathrm{~L}^{-1}$ & $14,02 \mathrm{a}$ & $61,12 \mathrm{a}$ & $4,37 \mathrm{a}$ & $9,12 \mathrm{a}$ & $16.79 \mathrm{a}$ \\
\hline Chitosan 1,5 mL L-1 & $12,95 \mathrm{a}$ & 53,48 a & $4,21 \mathrm{a}$ & $9,12 \mathrm{a}$ & $17.40 \mathrm{a}$ \\
\hline Chitosan 3 mL L-1 & $14,22 \mathrm{a}$ & $63,75 \mathrm{a}$ & $4,62 \mathrm{a}$ & $10,14 \mathrm{a}$ & $17.48 \mathrm{a}$ \\
\hline Chitosan 4,5 mL L-1 & $15,02 \mathrm{a}$ & $65,55 \mathrm{a}$ & $4,22 \mathrm{a}$ & 10,16 a & $17.12 \mathrm{a}$ \\
\hline
\end{tabular}

Keterangan : Nilai rata-rata yang ditandai dengan huruf kecil yang sama pada jenis pupuk organik padat atau pupuk organik cair chitosan tidak berbeda nyata menurut uji berganda Duncan pada taraf $5 \%$.

Tabel 2. Pengaruh Interaksi Pupuk Organik Padat dan Chitosan terhadap Daya Berkecambah Benih (\%).

\begin{tabular}{ccccc}
\hline \hline \multirow{3}{*}{ Pupuk Organik Padat } & \multicolumn{4}{c}{ Daya Berkecambah (\%) } \\
\cline { 2 - 5 } & $0 \mathrm{~mL} \mathrm{~L}^{-1}$ & $1,5 \mathrm{~mL} \mathrm{~L}^{-1}$ & $3 \mathrm{~mL} \mathrm{~L}^{-1}$ & $4,5 \mathrm{~mL} \mathrm{~L}^{-1}$ \\
\cline { 2 - 5 } & $93,4 \mathrm{a}$ & $99,2 \mathrm{a}$ & $99,2 \mathrm{a}$ & $100 \mathrm{a}$ \\
Tanpa Pupuk & $\mathrm{A}$ & $\mathrm{B}$ & $\mathrm{B}$ & $\mathrm{B}$ \\
Pupuk Kandang Ayam 20 & $100 \mathrm{c}$ & $99,2 \mathrm{a}$ & $99,2 \mathrm{a}$ & $100 \mathrm{a}$ \\
t ha-1 & $\mathrm{A}$ & $\mathrm{A}$ & $\mathrm{A}$ & $100 \mathrm{a}$ \\
Pupuk Kascing 7 t ha-1 & $97,5 \mathrm{~b}$ & $100 \mathrm{a}$ & $98,3 \mathrm{a}$ & $\mathrm{B}$ \\
\hline \hline
\end{tabular}

Keterangan : Angka yang ditandai oleh huruf besar dan huruf kecil yang sama pada kolom atau baris yang sama menunjukkan tidak berbeda nyata menurut Uji Jarak Berganda Duncan pada taraf $5 \%$. Untuk huruf besar dibaca ke kanan dan huruf kecil ke bawah

baik dalam mempengaruhi daya berkecambah benih adalah pupuk kandang ayam tanpa chitosan. Menurut Suprapto (2001) untuk pengisian dan pembentukan benih, unsur nitrogen, fosfat, dan kalium dibutuhkan oleh tanaman kedelai dalam jumlah yang berimbang dan cukup agar produksi dan mutu benih meningkat. Nitrogen merupakan sumber protein bagi benih, protrein merupakan senyawa penyusun fitin dalam benih yang berperan sebagai cadangan makanan. Kalium berfungsi meningkatkan sintesis dan translokasi karbohidrat untuk pengisian benih. Hasil sintesis yang ditranslokasikan ke dalam benih akan meningkatkan ukuran benih sehingga ukuran benih semakin besar dan cadangan makanan benih semakin banyak, sehingga kecambah normal kuat akan lebih banyak seiring dengan cadangan makanan benih yang meningkat dan cukup tersedia bagi benih untuk berkecambah. Dengan cadangan makanan yang banyak maka benih akan memiliki cukup energi untuk berkecambah sehingga viabilitas benih akan meningkat ditandai dengan persentase daya kecambah tinggi (Suprapto, 2001).

Indeks Vigor. Pemberian pupuk organik padat dan pupuk organik cair chitosan memberi- kan pengaruh yang nyata terhadap indeks vigor benih (Tabel 3).

Tabel 3 menunjukkan bahwa pemberian pupuk kandang ayam dapat mening-katkan indeks vigor benih dibandingkan dengan tanpa pupuk organik padat, tetapi tidak berbeda nyata dengan pemberian pupuk kascing. Indeks vigor maksi-mum dari benih buncis ini adalah 8, sedangkan indeks vigor rata-rata dari perlakuan yang memberikan pengaruh paling baik adalah sebesar 6,94. Dengan demikian indeks vigor dari benih yang dihasilkan sebesar 86,75 \% dari indeks vigor maksimum. Pupuk kandang ayam lebih cepat terdekomposisi dan mempunyai kandungan hara yang lebih tinggi dibandingkan dengan jumlah unit yang sama dengan pupuk kandang lainnya, sehingga dalam beberapa hasil penelitian pupuk kandang ayam menunjukkan respon yang baik terhadap tanaman (Widowati, 2006).

Sama halnya dengan pengaruhnya terhadap parameter daya berkecambah benih, kandungan unsur hara pada pupuk kandang ayam membantu dalam pembentukan benih yang baik dan kuat. Di dalam benih unsur $\mathrm{N}$ dan $\mathrm{P}$ diperlukan untuk menyusun senyawa fitin. Senyawa fitin di dalam benih berfungsi sebagai cadangan energi untuk 
berkecambah sehingga viabilitas dan vigor benih akan meningkat ditandai dengan persentase daya kecambah tinggi yang mempengaruhi persen keserempakan kecambah benih yang juga tinggi (Suprapto, 2001).

Tabel 3. Pengaruh Mandiri Konsentrasi Jenis Pupuk Organik Padat dan Pupuk Organik Cair Chitosan terhadap Indeks Vigor.

\begin{tabular}{lc}
\hline \hline \multicolumn{1}{c}{ Perlakuan } & Indeks Vigor \\
\hline Pupuk Organik Padat : & \\
Tanpa Pupuk & $6,64 \mathrm{a}$ \\
Pupuk Kandang Ayam 20 t ha-1 & $6,92 \mathrm{~b}$ \\
Pupuk Kascing 7 t ha-1 & $6,74 \mathrm{ab}$ \\
Pupuk Organik Cair : & \\
Chitosan 0 mL L-1 & $6,62 \mathrm{a}$ \\
Chitosan 1,5 mL L-1 & $6,76 \mathrm{ab}$ \\
Chitosan 3 $\mathrm{mL} \mathrm{L}^{-1}$ & $6,75 \mathrm{ab}$ \\
Chitosan 4,5 mL L-1 & $6,94 \mathrm{~b}$ \\
\hline \hline
\end{tabular}

Keterangan :Nilai rata-rata yang ditandai dengan huruf kecil yang sama pada jenis pupuk organik padat atau pupuk organik cair chitosan tidak berbeda nyata menurut uji berganda Duncan pada taraf $5 \%$

Pemberian pupuk organik cair chitosan dapat meningkatkan indeks vigor benih, kosentrasi 4,5 $\mathrm{mL} \mathrm{L}^{-1}$ menghasilkan indeks vigor yang lebih tinggi dibandingkan tanpa chitosan tetapi tidak berbeda dengan yang diberi 1,5 dan $3 \mathrm{~mL} \mathrm{~L}^{-1}$, sehingga konsentrasi 1,5 sudah cukup efektif untuk meningkatkan indeks vigor benih. Hal ini sejalan dengan penelitian Hadmoko (2011) dikutip Ritawati (2011) yang mengatakan bahwa pemberian chitosan dapat mempertahankan viabilitas benih kedelai selama dalam penyimpanan. Chitosan ini bersifat hidrofobik, dimana ia mampu mengikat air sehingga kandungan air dapat dipertahankan. Selain itu, chitosan termasuk salah satu jenis polisakarida yang dapat bersifat sebagai penghalang (barrier) yang baik karena pelapis polisakarida dapat membentuk vigor yang kuat (Grenner dan Fennema dikutip Ritawati, 2011).

\section{Kesimpulan}

Berdasarkan hasil percobaan, dapat ditarik kesimpulan sebagai berikut :

1. Pengaruh interaksi jenis pupuk organik padat dan chitosan hanya terjadi pada daya berkecambah benih. Pupuk kandang ayam tanpa chitosan merupakan perlakuan yang terbaik dalam menghasilkan daya berkecambah benih.

2. Pupuk kandang ayam dapat meningkatkan jumlah biji per tanaman, bobot biji per tana- man, dan indeks vigor yang paling baik.

3. Pemberian chitosan $1,5 \mathrm{~mL} \mathrm{~L}^{-1}$ merupakan perlakuan yang terbaik dalam meningkatkan indeks vigor benih.

Saran. Berdasarkan penelitian yang telah dilakukan, maka perlu dilakukan penelitan lebih lanjut dengan mengurangi dosis pupuk organic padat dan konsentrasi chitosan yang lebih tinggi untuk meningkatkan produksi buncis.

\section{Daftar Pustaka}

Balasubramanian, V dan M. Bell. 2005. Bahan Organik dan Pupuk Kandang. IRRI Rice Knowledge Bank. http://www.pustakadeptan.go.id Diakses pada 27 Januari 2012.

Chibu, H. and H. Shibayama, 2001. Effects of Chitosan Applications on The Growth of Several Crops. In: T. Uragami, K. Kurita, T. Fukamizo (Eds.), Chitin and Chitosan in Life Science, Yamaguchi, pp. 235-239.

FAO. 2011. FAOSTAT - Green bean production in Indonesia. http:/ / faostat3.fao.org/ home/index.html Diakses pada 9 Jan. 2013.

Mulat, T., 2003. Membuat dan Memanfaatkan Kascing Pupuk Organik Berkualitas. Agromedia Pustaka, Jakarta.

Musnamar, E. I. 2003. Pupuk Organik: Cair dan Padat, Pembuatan, Aplikasi. Penebar Swadaya. Jakarta. 72 hal.

Pitojo, S. 2004. Seri Penangkaran Benih Buncis. Kanisius. Yogyakarta.

Ritawati. 2011. Pengaruh Pemberian Beberapa Konsentrasi Kitosan dan Tingkat Kadar Air Benih Terhadap Viabilitas Dan Vigor Benih Kakao (Theobroma cacao L.) Selama dalam Penyimpanan. Thesis. Universitas Andalas.

Suprapto, 2001. Bertanam Kedelai. Penebar Swadaya. Jakarta. hal : 13-14.

Sutanto, R. 2002. Penerapan Pertanian Organik. Kanisius. Yogyakarta

Suwandi dan N, Nurtika, 1987. Pengaruh pupuk biokimia "Sari Humus" pada tanaman kubis. Bul. Penelitian Hortikultura 15(20):213-218.

Widowati, L.R. 2006. Pengaruh Kompos Pupuk Organik yang Diperkaya Bahan Mineral dan Pupuk Hayati Terhadap Sifat-sifat Tanah, Serapan Hara dan Produksi Sayuran Organik. Lap. Proyek Penelitian Balai Penelitian Tanah. Bogor.

Wulandini, R. 2002. Pemanfaatan Chitosan Dan Trichoderma harzianum Untuk Peningkatan Mutu Benih Pinus merkusii. Tesis. Institut Pertanian Bogor. 